\title{
'The sailor is a human being': Labour Market Regulation and the Australian Navigation Act 1912
}

\author{
Diane Kirkby
}

Labour lawyers wanting to broaden their field beyond the traditional narrowness of the employment relationship do so by employing a concept of regulation that has both economic and social objectives. They have called for law to be seen 'in the wider framework of social relations' with 'a longer time frame for analysis', and for an approach to the field which has an 'eye to both the future and the past $^{\prime} .{ }^{1}$ Their emphasis on the contextual factors impinging on and shaping labour law, its purpose and implementation, provides a compelling argument for historical research. As Michael Quinlan has pointed out, there is a complex interplay between context and purpose that is neither instrumental nor predetermined. ${ }^{2}$ Understanding the implementation of law thus requires historical, empirical research, to account for the particularities of its purpose and the unpredictable nature and direction of labour market regulation, which changes over time.

This chapter takes up the challenge to undertake sociolegal research, which expands our understanding of labour regulation. It focuses on the maritime workplace and a process of lawmaking for that workplace which has not previously been studied as it traces the origins and history of the Australian Navigation Act. In so doing, it broadens the field of labour law by accepting the labour market regulation approach which contextualises the employment relationship. It continues an argument for looking outside labour law narrowly defined that was begun in previous work on licensing laws and regulation of the hotel workforce. ${ }^{3}$ By looking at laws and their changing formulation, historians can reveal not only law's impact on the workplace in any particular instance, they can also offer perspective on the wider framework of the social history of labouring people.

\footnotetext{
1 Christopher Arup, Peter Gahan, John Howe, Richard Johnstone, Richard Mitchell, Anthony O'Donnell, eds, Labour Law and Labour Market Regulation: Essays on the Construction, Constitution and Regulation of Labour Market and Work Relationships (Sydney: The Federation Press, 2006), 11-12.

2 Michael Quinlan, 'Contextual Factors Shaping the Purpose of Labour Law: A Comparative Historical Perspective' in Arup et al, 21.

3 Diane Kirkby, Barmaids: A History of Women's Work in Pubs (Cambridge University Press, 1997); Kirkby, "“The Barmaid", "The Landlady", and "The Publican's Wife": History, Law and the Popular Culture of Women's Work in Pubs' in Romancing the Tomes, ed., Margaret Thornton (London: Cavendish, 2002), 167-83.
} 
The Australian federal government's announcement in 2009 that it was undertaking a process of reviewing the century-old Navigation Act offers an instance of lawmaking where the larger regulatory approach is particularly pertinent. Importantly, this was only the second time that a Labor government had undertaken to amend this legislation. It followed the 2008 report 'Rebuilding Australia's Coastal Shipping Industry' released by the House of Representatives Standing Committee on Infrastructure, Transport, Regional Development and Local Government, which covered coastal shipping policy then regulated under Part VI of the Navigation Act 1912. ${ }^{4}$ The purpose of rewriting the legislation was to implement the International Labour Organisation (ILO) Maritime Labour Convention (MLC) 2006 (No. 186) regarding the working conditions of seafarers on ships. ${ }^{5}$ The government's stated aim was to create 'a contemporary framework' for maritime safety and marine regulation by introducing 'greater flexibility' to allow the ILO amendments to be adopted and provide 'confidence and certainty for industry'. It consequently set up a process of consultation and invited responses from stakeholders, business, regulatory authorities, and unions.

The Maritime Union of Australia (MUA) responded, accepting that the legislation needed to be modernised but not on the grounds of allowing more flexibility for business. 'Regrettably, the term "flexibility for business" has come to mean a diminution of standards and a weakening of regulation, which is exactly the opposite of what is required in modernised maritime legislation' ${ }^{6}$ The Australian Shipowners Association (ASA) welcomed the possibility of benefits that might flow to the industry. The shipowners looked forward to having key shipping policy reforms enacted, the promise of having a new maritime regulatory regime to replace the existing 'cumbersome and complex legislation', a single national maritime jurisdiction, reduced uncertainty, removal of complexity and duplication, and 'a seamless transition from state to federal qualifications' ${ }^{7} \mathrm{~A}$ key proposal of the review was to replace eight separate state and territory jurisdictions with one federal regime.

The government's review (and subsequent introduction of the bill), however, provides a timely reminder of the importance of the Navigation Act to Australia's shipping industry history, and an opportunity to explore an example of federal regulation that is arguably as important in its impact on the maritime workforce as arbitration. Histories of Australia's industrial relations have not included

\footnotetext{
4 Australian Government, Department of Infrastructure, Transport, Regional Development and Local Government, Australian Maritime Safety Authority, Navigation Act Discussion Paper, 3 (Navigation Act Discussion Paper) http://www.infrastructure.gov.au accessed 1 November 2011.

5 ibid.

6 Maritime Union of Australia (MUA), Response to Issues Raised on Department of Infrastructure, Transport, Regional Development/AMSA Navigation Act 1912 Discussion Paper, August 2010, http://www. infrastructure.gov.au/maritime/paper/files/MUA.pdf accessed 1 November 2011.

7 'Navigation Act under Review', Ausmarine 32, no. 9 (July 2010): 15.
} 
discussions of the Navigation Act. ${ }^{8}$ Yet, its history is rightfully considered along with the better-known measures for regulation of the workplace given to the federal government. The constitution under section 51 authorised, and also confined, the federal parliament's power to legislate on industrial matters to the power to make laws to settle industrial disputes, which, like bushfires and rabbits, could cross state borders. As is well known, the Commonwealth used this power to set up the Court of Conciliation and Arbitration in 1904, but the constitution also gave the Commonwealth parliament an instrument for more direct regulation of the workplace.

Under the provisions of s. 51(1) read in conjunction with s. 98, which gave the Commonwealth parliament the power to regulate its overseas and interstate trade, terms and conditions for the employment of the workforce in the maritime industry were laid down and monitored by federal regulation under the Navigation Act. The special nature of work at sea prompted specific legislative regulations. Maritime workers employed in the coastal shipping trade crossed state borders regularly. They had been at the centre of the industrial disputes of the 1890s, which led to the arbitration power being included in the constitution at the time of federation. ${ }^{9}$ The mobility of this workforce, combined with the national economic (and defence) importance of merchant shipping to an island nation, produced a particular regulatory model as the two constitutional powers developed simultaneously as a conjunction of federal workplace regulation. Seafarers were regulated by both, and steered their course accordingly. The industrial importance of the Navigation Act cannot be underestimated, it is both historical and political.

\section{Origins}

The Australian statute's origins lay in the seventeenth century English Navigation Acts that were passed to develop English shipping by restricting the carriage of foreign trade to ships built, owned and crewed by English subjects, and reserving English coastal traffic for English shipping. This was the principle of cabotage. These acts, which were the foundation of the merchant marine and tied commerce and national defence together, were central as Britain rose to worldwide supremacy as a maritime power. ${ }^{10}$ According to the current

8 An example is Greg Patmore, Australian Labour History (Melbourne: Longman Cheshire, 1991).

9 Stuart Macintyre and Richard Mitchell, eds, Foundations of Arbitration (Melbourne: Oxford University Press, 1989), 9-11.

10 Ernest Fayle, 'The Navigation Acts', Edinburgh Review 228, no. 465 (July 1918): 22-42. 
government's discussion paper, 'These Acts covered a range of welfare and safety measures appropriate to the times to address the generally poor working conditions of seafarers and the high loss rate of both ships and lives' ${ }^{11}$

The Australian colonies were empowered under this English legislation to regulate their coastal trade, although this was subject to restrictions under the United Kingdom (UK) Merchant Shipping Act, which controlled 'British possessions'. 'A wide field of subjects was regarded as an Imperial preserve and merchant shipping for economic and political reasons associated with Britain's worldwide supremacy was in that field'. Thus, merchant shipping 'was the Imperial subject par excellence' ${ }^{12}$

The UK Merchant Shipping Act 1869 and later, 1894, 'charted the boundaries of the Colonial powers of legislation': s. 736 allowed colonial parliaments to regulate 'the coasting trade' (not specifically defined) on condition the legislation was reserved and confirmed by the United Kingdom, treated all British ships in like manner, and preserved the treaty rights of foreign states. Under the terms of the Act, colonial legislatures could pass legislation for vessels registered in the colony, 'provided such legislation is not repugnant to the Merchant Shipping Act $^{\prime} .{ }^{13}$ Coasting vessels were not those trading on lakes, rivers or within a port; but those which traded along the coast and sometimes, of necessity, voyaged beyond three miles from the coastline, so colonial statutes were still binding on the masters, crew and passengers of those vessels. The colonial acts passed by the various Australian legislatures were not overturned by the enactment of federal legislation but they were narrowed in their application to ships trading between ports within the particular state. ${ }^{14}$

Australia's efforts to develop its own federal laws were slow and difficult. A Commonwealth bill to apply on the Australian coast in substitution for important sections of the UK Merchant Shipping Act 1894 was originally drafted just a year after federation, in 1902, under the direction of Charles Cameron Kingston and, subsequently on his retirement, by Sir Harry Wollaston. It was introduced into the Senate in 1904, the same year as the Arbitration Act was passed, but then it was withdrawn and referred to a royal commission chaired by William (Billy) Hughes. In 1906, when a new UK Merchant Shipping Act was passed, the bill and the royal commission report were both presented to parliament and the next year were considered by an imperial Merchant Shipping Legislation conference that was held in London by representatives of the Australian, United Kingdom and New Zealand governments, along with British shipowners. The conference recommended 'that the coastal trade of the Commonwealth be reserved for ships

11 Navigation Act Discussion Paper.

12 Basil A. Helmore, 'Validity of State Navigation Acts', Australian Law Journal 27, (21 May 1953): 16.

13 ibid., 16.

14 ibid., 17. 
... conforming to Australian conditions, and licensed to trade on the Australian coast'. The bill was then revised and reintroduced into the Senate in 1907, 1908, 1910 and finally passed late in $1912 .^{15}$

The Bill was then reserved for the Royal Assent as required and, for many months in Britain and Australia, shipowners campaigned against its becoming law. British owners maintained that 'colonial' legislation ought not to apply to British ships. Australian owners objected that the Navigation Act would lead to an 'enormous increase' of their costs, for accommodation for each seaman would have to be almost doubled and compensation of sick and injured seamen would be greatly increased. ${ }^{16}$ Consequently the Act was shelved until after the 1914 federal election, and the outbreak of war postponed it further as the British government requested its implementation be delayed. ${ }^{17}$ Prime Minister Andrew Fisher announced it would be proclaimed in 1916, but it took until 1921 before the first sections, the Coasting Trade provisions, were proclaimed and it was not until 1923 that most of the other provisions were operative. At the time of the 1924 royal commission, 46 of 425 sections (most of them dealing with pilots and pilotage) still remained inoperative.

The purpose for passing the Navigation Act, 'which actuated the Parliament ... and which lifted the subject to a plane of great importance above the ordinary considerations of party politics, was', in the view of royal commissioners J.H. Prowse and A.C. Seabrook, 'the desire to build an Australian Mercantile Marine' ${ }^{18}$ To do this, the commissioners said, Australian shipowners needed to be protected 'from subsidised foreign ships or poorly paid crews', so it was necessary to ensure all ships had the same manning scale, paid their crews Australian wage rates and provided them with the same accommodation. In order to achieve this 'the Australian coastal trade was to be reserved for Australian-owned ships, which were to be the source of a supply of skilled and trained Australian seamen in time of war'. Parliament regarded having an Australian Mercantile Marine as a matter of national security, of such national importance that higher freight rates was a price that had to be paid. ${ }^{19}$

This - applying the principle of cabotage — was in keeping with the spirit of the original British navigation acts, but it went further. According to Percy Clarey, former president of the Australian Council of Trade Unions (ACTU) and, by 1952, a Labor member of parliament, 'the Navigation Act was an earnest attempt on the part of the Australian parliament to give seamen reasonable

15 Royal Commission on the Navigation Act, 1924 (Royal Commission 1924), Report (Melbourne: Government Printer, 1924), 2.

16 Brian Fitzpatrick and Rowan Cahill, The Seamen's Union of Australia, 1872-1972: A History (Sydney:

Seamen's Union of Australia, 1981), 47.

17 Royal Commission 1924, 2.

18 ibid.

19 ibid. 
and decent conditions of employment, and make the maritime industry as safe as possible'. And, at the time it was passed, in 1912, he said, it was 'the best navigation act in the world ... ${ }^{20}$

This Navigation Act, which specifically did not apply to the navy, applied only to 'British' ships, covered ships engaged in trade and commerce, taking on board and carrying passengers, or cargo, from and between ports in the Commonwealth and from there to foreign ports. The Act stipulated the number and nature of crews. All such ships had to have a duly certificated master and officers of differing grades (first mate, second mate, and engineers of various grades) who had to be British subjects and English-speaking. It included provisions relating to the qualifications of officers; the supply, engagement and discharge of crews; the payment of their wages, health and accident benefits, discipline and accommodation; as well as provisions as to safety, equipment, unseaworthy ships, and prevention of collisions. ${ }^{21}$

Division 4 on seamen applied to both British and foreign ships, covered methods of employment, apprenticeships, terms for becoming a rating (ABS or able bodied seaman after three years apprenticeship, and being 18 years old; an OS or ordinary seaman after one year at sea, minimum age 17 years old) all of which had to be verified with paperwork; a seaman could be 'disrated' by the master who had to record it in the logbook and provide the seaman with a copy; specified the number of crew to be employed; the procedures for establishing terms of agreement for employment and subsequent discharge from a ship; prohibited the payment of wages in advance; enabled the payment by 'allotment' of wages to family members; and procedures for deductions and payment on discharge. Division 12 of the Navigation Act 1912 was on Discipline. Any master, seaman or apprentice who by wilful breach or neglect of duty or drunkenness' caused or failed to prevent damage or loss to the ship or its cargo was guilty of an indictable offence. Smuggling was an offence for seamen, assault was an offence if committed by an officer. ${ }^{22}$

\section{Revisions and amendments}

Just three years after it came into effect, in 1924, the government set up a royal commission to investigate whether the Navigation Act had succeeded in its purpose of developing an Australian merchant marine. The commissioners could not agree, so their report contained three different positions and three different sets of recommendations. The first report was produced by the chairman (J.H.

20 Australia, Parliament, Hansard, 1952, 3690.

21 Helmore, 17.

22 Australia, Statutes, Navigation Act, 1912, ss. 28-33; ss. 99-115. 
Prowse, MP) and another commissioner (A.C. Seabrook, MP); the second by Labor parliamentarians Frank Anstey MP, Senator C.S. McHugh, and G.E. Yates MP; and the third by two Senators W.L. Duncan and H.E. Elliott.

Prowse and Seabrook were unequivocal that the Navigation Act had failed to develop an Australian merchant marine; Anstey, McHugh and Yates were equally sure that the attack on the Navigation Act from the Tariff Board alleging that the Act had caused Australian trade to suffer, was ill-founded; Duncan and Elliott argued that repeal of the Act would doubtless 'bring more foreign and non-British competition which would react very quickly against the wages and working conditions of our Australian seamen and against the best interests of Australia as a whole, unless some other form of protection be given' ${ }^{23}$ Put simply Australia, as an island continent, was heavily dependent on shipping, and could not afford to increase its dependence on foreign shipping for the marketing overseas of its primary products. Australian seafarers were necessarily protected because the merchant marine was nationally important both for economic and defence purposes. It was a principle written into law from the beginning, and which was subsequently maintained in later emendations. The two Labor MPs (Anstey and Yates) in their minority report recommended that official administration of the Act should be changed and the director (who was thought to be too sympathetic to shipowners) made directly responsible to a minister. ${ }^{24}$

While they waited for the Navigation Act to become law, the Seamen's Union of Australia (SUA) pushed their claims through the Arbitration Court where they won many of the same conditions as had been given to them in the Navigation Act. ${ }^{25}$ When the Navigation Act finally became operational in the 1920s the SUA 'was jealous to see that its protective provisions were enforced': that Australian wages and conditions applied on ships trading on the Australian coast, that the provisions of the Act were sufficiently adhered to regarding unsafe practices, that damaged or overloaded ships, with improperly stowed cargo did not get clearances to sail from the Department of Navigation. When the SUA was deregistered in 1925 and no longer had an award under the Conciliation and Arbitration Court, the only safeguard the union had for their conditions was the Navigation Act, but shipowners refused to comply with the SUA demand that award conditions be incorporated into ships' articles of employment. ${ }^{26}$ In 1925, this led to a three-month strike, which was part of a larger international industrial action. The 1930s were even tougher for seafarers, a huge strike in

23 Royal Commission, 1924, 78.

24 ibid., 65; see also Fitzpatrick and Cahill, 58.

25 Fitzpatrick and Cahill, 48.

26 ibid., 57-58. 
1935 left the union devastated and led to a change in leadership. ${ }^{27}$ Amendments made to the Navigation Act in that year, however, were not substantive in their impact on the workforce.

During the Second World War, the defence role of the merchant marine became crucial as Australian shipping carried troops and materials overseas and around the coast. Merchant shipping was administered by the Department of Supply, by which means the government chartered ships and shipowners acted as managers on the government's behalf. The SUA claimed its fight for seafarers' rights was 'just as fierce as any fight in warfare', but joined the war effort and cautioned members against sparking disputes over comparatively trivial issues which could strengthen shipowners and government opposition. ${ }^{28}$ With the coming of war to the Pacific, in 1942 the Curtin Labor government, under the National Security Regulations, set up the Maritime Industry Commission (MIC) whose task was 'to secure the adequate and efficient manning of Australian merchant ships and the improvement and safeguarding' of their crews. ${ }^{29}$ This was a tribunal authorised under special wartime conditions to deal with industrial matters that were traditionally covered within the jurisdiction of the arbitration system. It was chaired by former New South Wales industrial commissioner Justice de Baun, and consisted of representatives from each of the interested parties - three employer representatives for the shipowners, one nominee for the government, and four representatives from the several maritime unions, the Merchant Service Guild and the Australian Institute of Marine and Power Engineers which covered the officers; the Marine Cooks, Bakers and Butchers union which covered the catering crew and, for the deck crew, the Seamen's Union. ${ }^{30}$

The MIC had the power to make an order become law notwithstanding existing Commonwealth or state laws or awards of industrial tribunals, but it could not reduce the conditions of seafarers nor take actions that would impact negatively on the efficient, adequate manning of a ship. ${ }^{31}$ The SUA welcomed the new commission. 'It is obvious the MIC has unlimited power - always keeping in mind it can only "improve and safeguard"', the Seamen's Journal reported. 'Marine unions can now avail themselves of the Commission to secure for their seamen the best living and working conditions in the world'. ${ }^{32}$

With this in mind, the SUA, through the MIC, was able during the war to gain for its members shorter working hours (from the 56-hour week to the 44-hour week)

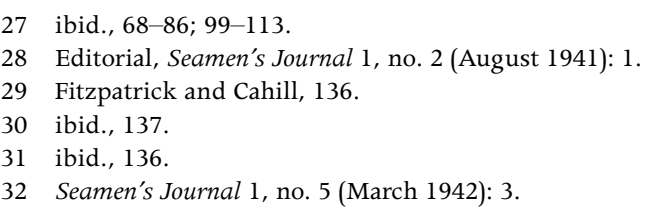


they had been arguing for unsuccessfully in the Arbitration Court, increased wages to a level well above that of the regular navy, and improved accommodation - separate rooms for each watch, individual clothes lockers, change rooms, mess rooms with refrigerator - more improvements in one year than in the previous $25 .{ }^{33}$ Their efforts to have meals and catering equivalent to that of the officers were less successful. The war years were turbulent as the SUA exerted its industrial strength and the MIC spent much time deciding misconduct cases and imposing disciplinary measures on seafarers held responsible for holding up shipping. ${ }^{34}$ Nevertheless, these were years of comparative industrial peace and the SUA made gains without resorting to the procedures of arbitration. At the end of the war, under the Chifley Labor government, the MIC continued to deal with matters that would otherwise have gone to the Arbitration Court. ${ }^{35}$ The SUA was successful in winning improvements to their conditions by actively disrupting the Australian post-war shipping trade with stoppages that, by the early 1950s, members of the Menzies conservative government claimed were both too frequent and unjustified. They used the machinery of the Navigation Act to force the unions back into the Arbitration Court.

When the Menzies government came to power in 1949, the maritime and stevedoring industries, in what Menzies called 'Australia's vital shipping industry', had the reputation for having the most troubled and difficult industrial relations records in Australia. ${ }^{36}$ In the overheated and what historian Tom Sheridan describes as the 'miasma of Cold War propaganda', the reality of workplace disputes was often lost in charge and countercharge of class warfare and secret agendas. ${ }^{37}$ At least one Arbitration Court judge saw seafarers as working in dreadful and degrading conditions that it was the court's task to improve, while the Menzies government saw industrial laws and arbitration court processes as a means to combat communists and clamp down on industrial militancy. These were less direct, more covert laws than the failed initiatives - the Communist Party Dissolution Act 1950, which was challenged in the High Court by the SUA, the Waterside Workers Federation (WWF) and several other unions, and found to be unconstitutional, and the subsequent referendum of 1951 which was also defeated by a narrow vote. ${ }^{38}$ As the Cold War battle lines hardened, the government's agenda for dealing with communists was implemented through other less direct, more specifically targeted, measures.

\footnotetext{
33 Fitzpatrick and Cahill, 148-49.

34 ibid., 159

35 Seamen's Journal 4, no. 11 (February 1948: 4.

36 Tom Sheridan, Australia's Own Cold War: The Waterfront under Menzies (Melbourne University Press,

2006), 95.

37 ibid.

38 ibid., 96.
} 
Penal sanctions were introduced into the Arbitration Act and amendments were made in 1952 to the Navigation Act, which others have claimed were 'a direct threat to communist power' in the leadership of the SUA. ${ }^{39}$

Understanding the Menzies government's amendments to the Navigation Act begins with the long-standing militancy of the Seamen's Union to win concessions from shipowners, now compounded in the post-war climate by a boom in shipping, an ageing fleet of ships, and the ideological battle lines of the Cold War. Led since 1941 by Eliot V. Elliott, described in the parliamentary debate as 'a self-confessed well-known Communist', the SUA was, like the WWF, held up as being Kremlin-dominated. ${ }^{40}$ There is evidence that the government also recognised that much of the cause for disputation rested with the shipowners, 'the relative inefficiency of the private sector [which] rested on the twin historical handicaps of an ageing capital stock and a backwardlooking management mindset which misjudged market trends' ${ }^{41}$ But, publicly and politically, this was never acknowledged.

In the 1950s Australian coastal shipping companies were, unlike overseas companies, protected from 'unfair' foreign competition by the relevant cabotage provisions of Australia's Navigation Act. However land transport was now a direct and growing competition, they also faced potential competition from the federal government-owned shipping line, while the militancy of the SUA was exerting pressure on their labour costs. ${ }^{42}$ In this context, the Menzies government's free enterprise ideology pointed to a policy to prevent the government fleet from undermining the profits of the private shipping companies but, the inability of those companies to meet demand meant that the government had to expand its own fleet. Nevertheless, private shipowners were sheltered from the full impact of both market forces and the more profitable national shipping line as the government made every effort to prevent the publicly funded line from injuring private interests' ${ }^{43}$ As Sheridan says, 'unquestionably, coastal shipowners were fortunate that the Coalition government, and more particularly Prime Minister Menzies, remained in office' ${ }^{44}$

With these economic considerations guiding policy, the government's alterations to the Navigation Act were consistent with the economic advantage that could be

39 Fitzpatrick and Cahill, 235.

40 Hansard, 1952, 3682; Sheridan, 89 et seq.

41 Tom Sheridan, 'Coastal Shipping and the Menzies Government 1950-1966', Australian Economic History Review 25 (March 1995): 3.

42 ibid., 3-4.

43 ibid., 4.

44 Sheridan, Australia's Own Cold War, 17. 
gained by hobbling union militancy. The 1952 Bill proposed 'some revolutionary amendments' in the employment conditions of seafarers that Labor MPs claimed would 'not be in the best interests of Australia' . ${ }^{45}$

The essence of the 1952 Bill revolved around three key issues. Firstly, it abolished the MIC. For a decade, the MIC, consisting of representatives from the shipowners, the government and the unions, had handled disputes that would otherwise have gone to the Arbitration Court. In bringing the maritime industry within the general framework of the arbitration and conciliation system, the government's reform sought 'to tidy up a system of boards and commissions ... different rules and different interpretations of discipline applied to different industries' thereby imposing the same discipline on the maritime industry as the court imposed on other industries. It was bringing a 'new approach to discipline on the waterfront ${ }^{\prime}{ }^{46}$

In Labor's or, more specifically, its leader, H.V. Evatt's, view, the MIC should have been strengthened instead of being disbanded. ${ }^{47}$ Similarly, the MP Clyde Cameron pointed to the advantages of informality, the in-camera hearings, the trust and confidentiality of discussion conducted with 'common sense and amicable manner' within a committee framework. Experience suggested that industrial relations were best conducted around a table rather than in the adversarial formal proceedings of a courtroom. ${ }^{48}$ Another MP reminded the parliament that 'the sailor is a human being' and should be treated as such. ${ }^{49}$ To the government the MIC's task was not to settle industrial disputes nor had it been successful in doing so. ${ }^{50}$ The fact that SUA Federal Secretary Elliott sat on the MIC meant critics and the government had easy ammunition to charge that 'communists sit on the MIC' thereby discrediting the MIC itself. ${ }^{51}$ The Labor party pointed out that the government had introduced the measure without consultation with those in the industry: 'no responsible member of the MIC, no representative of the employees' organizations and ... no representative of the employers knew that this measure was to be introduced ...' and the bill contained 'nothing which in itself will provide a remedy for the evils which the Minister has mentioned' ${ }^{52}$

Furthermore, in replacing the MIC, the Bill gave arbitration power to a single judge of the Conciliation and Arbitration Court and set up a separate committee to deal with issues of accommodation - both designed to reduce disputes

\footnotetext{
Clarey, Hansard, 1952, 3690.

Freeth, Hansard, 3679.

Evatt, Hansard, 1952, 3666

Cameron, Hansard, 1952, 3675.

Haylen, Hansard 1952, 4316.

Holt, Hansard, 1952, 3423.

Howse, Hansard, 1952, 3682.

Evatt, Hansard, 1952, 3667.
} 
generated by the maritime unions about their working conditions. The crew accommodation committee was to consist of trade union and shipowner representatives 'assisted by the expert advice of governmental shipping and shipbuilding officers' and was to 'be empowered to make orders' giving effect to its decisions. ${ }^{53}$ By this means, the Act replaced a commission with a court, removed union representation from deliberations, and replaced committee decision-making with judicial power. Cameron said, 'If this bill is aimed at the Seamen's Union of Australia, although the Minister did not say so, that union will be no more co-operative with an arbitration court judge than it has been with the MIC'. He asked, reasonably, 'Why should it be?' and why could not the same power that was being given to a single judge instead be given to the MIC ${ }^{54}$ Removing the MIC and its union representation removed the important role that the SUA had played in the decision-making process affecting the workplace.

Most notably, the legislation tightened the 'disciplinary clauses to control seamen', by 'radically chang[ing] the definition of desertion' and increasing the penalty attached to being a 'deserter'.$^{55}$ Desertion by a seafarer was now defined as being absent from his ship for more than 48 hours without leave or reasonable excuse, even if the ship was in port for weeks. ${ }^{56}$ This compared unfavourably with the previous definition, which made the intention of not returning to the ship the essence of the charge; that is, intention had to be proved for the charge of desertion to be maintained, which courts had difficulty doing. Now, absence in itself was held to be desertion, and the onus was placed on the seafarer to show he had a lawful or reasonable excuse for his absence. ${ }^{57}$ The Bill also amended provisions relating to actions obstructing or interfering with officers 'and harbouring or secreting deserting seamen or apprentices'. ${ }^{58}$ The SUA pointed out that 'the new law is aimed directly at every man who goes to sea regardless of rank or rating'. ${ }^{59}$ 'Failure to obey' orders to take a ship to sea, subjected both 'officers and crew to a penalty of immediate dismissal, loss of repatriation to a home port, loss of accumulated leave, and a bad discharge which may mean exclusion from employment in the shipping industry' ${ }^{60}$

Union officials could be held responsible for engaging seafarers as crew and punished with gaol for failure to obey, or for persuading seafarers to commit a breach of their agreement. ${ }^{61}$ Furthermore, the Act gave power and responsibility to approve or refuse employment on board ship to a single individual ('a

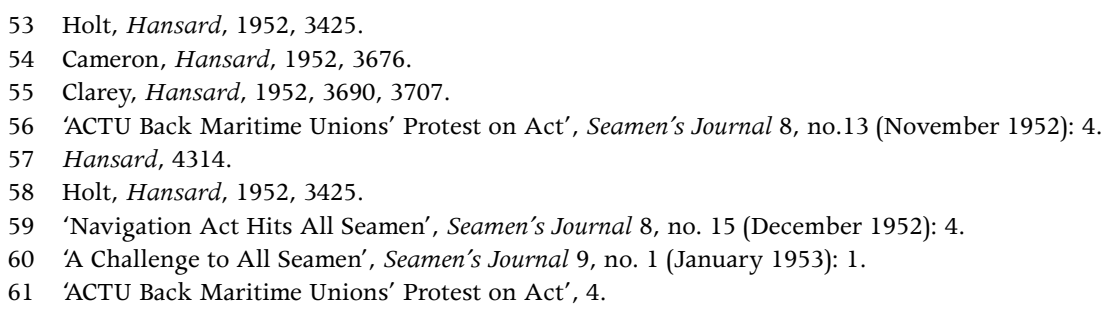


superintendent') whose refusal may have no connection to any ship-related offence at all, something which had previously been decided by representatives of employers and employees meeting in conference in the MIC. ${ }^{62}$ The government claimed it was preserving much of what the commission had done, especially in the area of discipline, but the Labor party saw it as contradictory to preserve the principles and practices while not preserving the commission itself. ${ }^{63}$ Desertion meant a seaman was thus given a bad discharge from a ship and, under the new provisions, there was no provision for a seaman to appeal a bad discharge given by a master, yet three bad discharges excluded him from further employment. The Act took away the right to give a man a second chance, something the MIC had the power and discretion to do. ${ }^{64}$ 'Let there be no doubt in anyone's mind that to refuse to take a ship to sea after being ordered to by the Master ... starts [a seafarer] on the way out of the industry', the SUA alerted their members, 'it is possible never to have received a bad discharge and yet to be excluded from the industry'. A 'very good conduct does not cancel out a report which is bad within the meaning of the Act' ${ }^{65}$

The amended Navigation Act passed through parliament quickly and came into force early in 1953. A new industrial award, the Seamen's Award, followed in the Arbitration Court in 1955 which, when the SUA challenged it in the High Court in 1957, was upheld as valid. ${ }^{66}$ Further amendments - 'far worse than the amendments which the ACTU strenuously opposed in 1952' - were made to the Navigation Act and rushed through parliament in $1958 .{ }^{67}$ These amendments, again introduced into parliament without either the unions or the shipowners being given prior warning, imposed new and heavier penalties that deprived seamen of further rights. The government had held discussions on an earlier draft more than two years previously but when the bill was eventually introduced it included new provisions not contained in the 1955 draft, specifically 'vital clauses abolishing the rights of seamen' ${ }^{68}$ Despite a hastily organised deputation to the minister from all the seagoing unions (Merchant Service Guild, Marine Engineers, Radio Operators, Stewards, Cooks and SUA) which was neatly foiled by the minister being unavailable that particular day, combined with strong opposition from the Maritime Transport Council, and the Labor Party opposition on the floor of the House, the amended Act was hurriedly passed into law. The Maritime Transport Council considered the new clauses 'most dangerous' and that they would 'worsen the conditions

62 Hansard, 1952, 3665.

63 Holt, Hansard, 1952, 3423.

64 Cameron, Hansard, 1952, 3677.

65 'Let's Be Clear About This Act', Seamen's Journal 9, no. 15 (December 1953): 3.

66 High Court of Australia, Queen v. Spicer and Others: Ex Parte Seamen's Union of Australia, Commonwealth

Law Reports, 96, 1957, 341-52.

67 Seamen's Journal 13, no. 3 (April 1958): 6

68 'Navigation Act', Seamen's Journal 13, no. 5 (June 1958): 3. 
of seamen'. ${ }^{69}$ Indeed, in the campaign for a new award that the SUA waged between 1958-60, the penal provisions of the Navigation Act were frequently used against individual seafarers. ${ }^{70}$ The SUA declared the Menzies government's refusal to listen to seafarers on the realities of their workplace conditions, even when presented through a committee of shipowner and union representatives established by the government itself, reflected an 'attitude of contempt towards the unions and all who work' ${ }^{\prime 1}$ With these two pieces of industrial relations law - the Arbitration Act and the Navigation Act - acting in tandem, all seafarers had their job security, conditions, wages and their safety jeopardised without addressing the inefficiencies of the shipowners. As a consequence, arguably and perhaps not coincidentally, the amended Navigation Act was instrumental in setting back the working conditions of ordinary seafarers for another 15 years. The SUA's agenda for stabilising and normalising their working conditions, which had been presented to shipowners as early as 1946, was not finally achieved until the mid 1960s. ${ }^{72}$

The Navigation Act 1912 has been amended many times since its inception but, from 1952, those changes were made consistently by Liberal Coalition governments, in conjunction with penal sanctions and more limitations being imposed on trade unions under the arbitration law. By 1979, when Prime Minister Malcolm Fraser was amending simultaneously both the Navigation Act and other industrial relations laws, seafarers were describing the Navigation Act as 'one of the most vicious pieces of legislation to be drawn up against a group of Australian workers'.$^{73}$ Calling it 'unjust and one-sided' with provisions that ought to have been rescinded years previously, union members found the most disturbing aspect of the penalties under the Act was the fact that seamen's rights of defence were very limited, indeed, in most instances were non-existent. 'When a seaman is fined and logged his only defence is his right of reply to the Master's log entry', the SUA pointed out, and appeals to the Marine Council were a waste of time. 'Very rarely does the Council alter or rescind any fine or log entry.' Consequently seafarers felt themselves to be powerless to prevent injustices, 'We have not got the right to refuse to pay a fine if we think we were dealt with unjustly ... [it just] can be deducted from your wages' ${ }^{74}$

By the time of the Labor government's review in 2010, the regulatory regime of industrial relations had been restructured, enterprise bargaining and the Fair Work Act replaced the older machinery of arbitration, and the maritime

69 Seamen's Journal 13, no. 3 (April 1958): 6; 'Amended Navigation Act', Seamen's Journal 13, no. 5 (June 1958): 5

70 Fitzpatrick and Cahill, 276.

71 'Navigation Act: Government Ignores Committee of Advice', Seamen's Journal 13, no. 5 (June 1958): 7-8.

72 Fitzpatrick and Cahill, 238.

73 H. Leonard, 'Navigation Act Vicious, Biased', Seamen's Journal 34, no. 8 (December 1979): 247.

74 ibid. 
workforce was no longer a merchant marine based on the navy's models of hierarchy. ${ }^{75}$ The Coalition government's review of the legislation reported in 2000 that 'there are several provisions in the legislation that address employment arrangements for seafarers that would more appropriately be addressed under modern company based employment arrangements governed by modern industrial relations legislation' ${ }^{76}$ Moves had begun to move employment aspects out of the Navigation Act but, significantly, this report saw safety of shipping as unconnected to workplace relations: 'In some cases, industrial and safety considerations have been intermingled. It is appropriate that these be separated to establish a clear focus on essential health and safety requirements in law, whilst enabling employers and employees greater freedom to negotiate on industrial matters'. Nevertheless the report also recognised that, 'Work at sea, however, presents some unique circumstances and it is appropriate that shipping law continue to provide for conditions that reflect safe operations and reflect particular industry characteristics' ${ }^{77}$ In other words, the maritime workplace continued to have its own very complex regulatory regime of which the Navigation Act is only one part.

\section{Conclusion}

The amendments and the debates over the Navigation Act are an insight in to what Sir Richard Kirby, former president of the Industrial Relations Commission, once called 'the very human problems bound up in industrial relations' that 'a scientific approach based on law, economics or any field of learning would not on its own solve'.$^{78}$ The history of the Navigation Act is a window on to this world. It follows a similar trajectory as the history of arbitration, as it moved from being 'the best Act in the world' protecting Australian industry, shipowners and maritime workers, to a mechanism for implementing punitive sanctions and reducing the bargaining power of the unions as companies trading on the coast faced increasing competition.

The review undertaken by the current Labor government, under Prime Minister Julia Gillard, was begun with the view that, a century later, Australia's international trade continues to be dependent on shipping, that coastal shipping is thus vital to the national economy, and a key segment of the transport industry. ${ }^{79}$ The 2008 discussion paper made clear that the Navigation

75 For an account of the restructuring of Australia's seagoing workforce, see Diane Kirkby, Voices From the Ships: Australia's Seafarers and Their Union (Sydney: UNSW Press, 2008), 350-66.

76 Review of the Navigation Act 1912, Final Report, 2000, i.

77 ibid.

78 Richard Kirby, A New Province for Law and Order (Robert Garran Memorial Lecture: Canberra, 1968$), 13$.

79 Navigation Act Discussion Paper. 
Act 1912 was now outdated, yet the government did not intend to rewrite its substantive provisions but rather, to modernise and clarify the current regulatory framework so changes would be 'predominantly of a technical nature' ${ }^{80}$ Prompted by the ILO and its MLC 2006 (no. 186) setting minimum requirements in the conditions of employment for seafarers to work on a ship, viz: 'hours of work and rest, accommodation, recreational facilities, food and catering, occupational health and safety protection, medical care, welfare and social security protection', the federal government set about establishing appropriate mechanisms for compliance, 'through formalised inspection and certification compliance procedures, shipowners' and shipmasters' supervision of conditions on ships, flag state jurisdiction and control over local ships, and port state inspection of foreign ships'. Put simply, the Navigation Act was being rewritten because it was 'the main legislative vehicle for implementing the MLC at the Commonwealth level' ${ }^{81}$

Nevertheless, as the first Navigation Act to be amended by a Labor government since 1942, it constitutes a significant moment of Australian industrial lawmaking. While it remains to be seen what this current legislative rewriting brings to the revitalisation of Australian coastal shipping, it is a significant step in regulating the 'very human problems' of safety and security of its maritime workforce that are inherent, but not always acknowledged, in the employment relationship. 